\title{
Continuation or Evolution? Changes in Pottery Production and Vessel Types Used in Pomerelian (Gdańsk Pomerania) Towns in the Early-Modern Period
}

\author{
Michał Starski $^{a}$
}

\begin{abstract}
The article discusses changes in production and assortment of the pottery used in towns in Pomerelia (Gdańsk Pomerania) in the early-modern period. These considerations are based on advanced research on late-medieval pottery-making of the region and the relatively poorer state of knowledge about the continuity of transformations at the beginning of the early-modern period. The vantage point for this study is a characterisation of the source base, including both the artefactual and written evidence. This enables the tracing of changes, and characteristic features of goods used, in the 16th century.
\end{abstract}

KEY-WORDS: ceramics, pottery, Pomerelia, Gdańsk Pomerania, early-modern, towns

\section{INTRODUCTION}

The I6th century was a time of significant cultural changes occurring throughout Europe. These transformations were heralded, as evident already at the end of the late Middle Ages, by the dissemination of Renaissance ideas, including the Reformation, as well as developments in material living conditions of the people, for instance in construction technology or assortments of handicraft products available. These aspects fuelled cultural change within different social strata and thus impacted the formation of the modern society. One of the domains showing signs of innovation were households which, as one of the primary areas of functioning of human life, would undergo constant reconfigurations. Against the backdrop of other domains, such as architecture, painting, or fashion history, these reconfigurations have so far not been analysed specifically for the i6th century in relation to the region of Pomerelia (Gdańsk Pomerania).

a Faculty of Archaeology, University of Warsaw, Krakowskie Przedmieście 26/28, 00-927 Warsaw, Poland; e-mail: m.starski@uw.edu.pl; https://orcid.org/oooo-oooI-7995-8788 
Io $\mid$ Michat Starski

The aforementioned situation applies also to pottery production and the variety of available ceramic goods that, in Polish lands, would change relatively little at that time.

This article aims to characterise the pottery production and the assortment of ceramic goods used in Pomerelian towns in the early-modern period. This should enable outlining one of the developmental stages in the history of pottery-making, coinciding with the 16 th century and important for understanding adaptations occurring in consumption, the spread of new production techniques and pottery forms, as well as stronger supra-regional relationships and long-range trade in these goods. Within the discussed area, this period saw the establishment of specialised centres of craftsmanship, potentially including pottery production. However, the exact influence of these processes on the subject of research remains vague.

A limitation of these studies is their upper chronological boundary, artificially set to the beginning, or the first half, of the i6th century. Such an approach, so far dictated by research possibilities, openly precludes any characterisation of continuity in the transition between the medieval and early-modern periods. Hence, it is important to consider continuity in regard to distinguishing features of pottery of the declining stages of the late Middle Ages and its evolution in the face of innovations. Addressing this question is currently possible thanks to an increasing amount of material evidence from archaeological investigations, an important supplement to which comes from the written evidence. However, the existing state of research does not enable anything more than outlining the most important tendencies in need of further studies.

\section{TERRITORY}

At the beginning of the early-modern period, the urban network in Pomerelia already functioned as a mature structure (Fig. I). It consisted of I8 smaller townships, whereas a central role was played by the agglomeration of Gdańsk (Biskup 1980: 405; Grzegorz 1988: 49-50; 2007: I20-I25; Czaja 2000: 45-65). The smaller towns acted as local centres of handicraft production and trade, with populations not exceeding two thousand residents, as can be inferred from registers preserved in sources written in the third quarter of the i6th century. This group of settlements included several semi-agricultural ones, containing fewer than one thousand individuals. Gdańsk clearly stood out against this background, with a population of above 40 thousand inhabitants (Źródta dziejowe 19II: 98-288; Gierszewski 1966: 15-25; Bogucka and Samsonowicz 1986: 373). In the 16th century, it was one of the most important Baltic towns, a centre of culture and trade for the whole Polish-Lithuanian Commonwealth. Thanks to its role in the riverine trade on the Vistula, Gdańsk maintained wide commercial relations with the majority of Polish towns and the main economic centres. Its economic position and cultural influence on the local hinterland were pivotal for the economic situation of the whole 


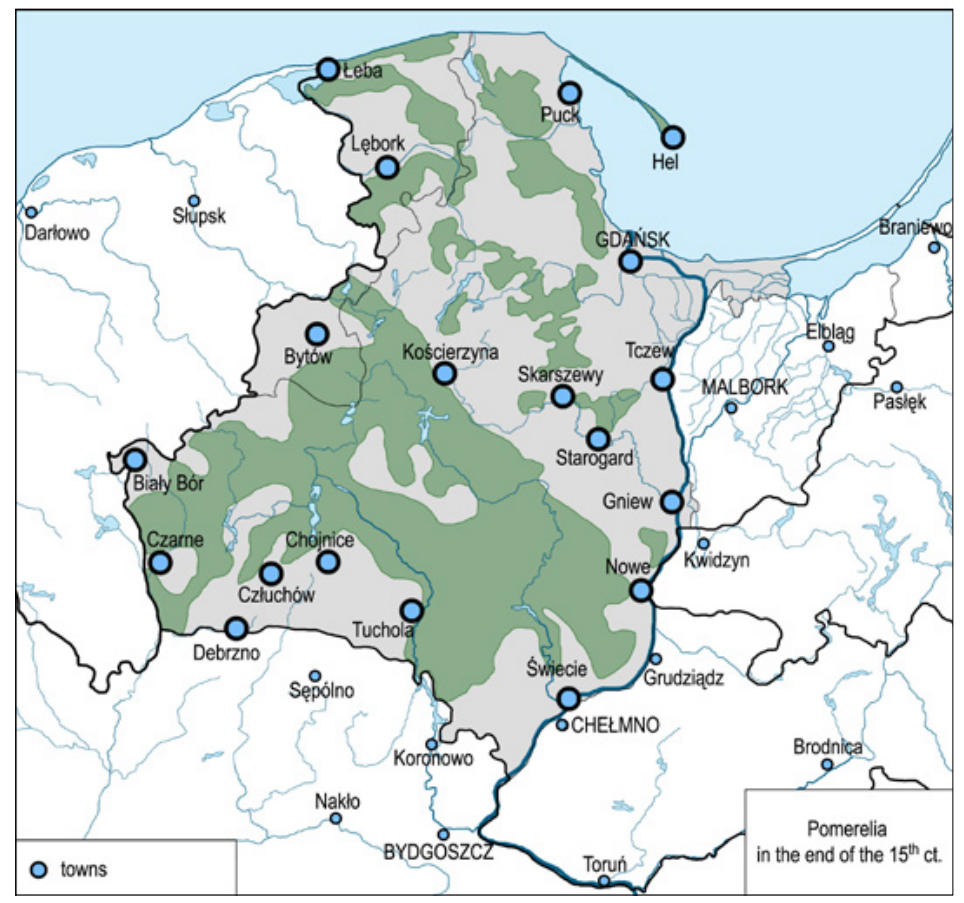

Fig. 1. The Pomerelian urban network in the 16th century shown in the context of the region's afforestation. Prepared by M. Starski.

region in the period under discussion here. Smaller townships, maintaining relations with the main centre, benefitted from its demand for raw materials and handicraft products. Through this process, innovations would find their way into production techniques and assortment of available goods, as well as new ideas. In the majority of the smaller towns, similarly to Gdańsk, the Reformation was gaining momentum, while architecture saw the adaptation of new stylistic solutions (Gierszewski 1966: I2-23; Czaja 2000: 45-65; Grzegorz 2007: I2O-I25; Ptaszyński 20I8: II2-II4). In this regard, the discussed period, despite its relatively narrow chronological span, forms a coherent whole in terms of economic and cultural changes.

\section{THE PRODUCTION AND CHARACTERISTICS OF POTTERY AT THE END OF THE LATE-MEDIEVAL PERIOD}

The vantage point for studies on early-modern pottery of the region is provided by the previous scholarship on pottery-making and assortment of goods used at the end of 
I2 $\mid$ Michat Starski

the late-medieval period. Numerous assemblages dated to the earlier of these periods have been obtained in Gdańsk as well as in Chojnice, Lębork, and Puck (Tab. I). Smaller, but still representative, assemblages have come also from Bytów, Człuchów, Gniew (Tczew distr.), and Skarszewy (Starogard Gdański distr.), whereas finds from Debrzno (Człuchów distr.), Starogard Gdański, Tczew, and Tuchola are of secondary importance. Not all of this material has already been published, but one might list at least about a dozen works and unpublished compilations shedding light on the character of pottery production in Pomerelian towns (see list in Starski 20IO; 20I6a).

Table 1. Quantification of different pottery types in selected assemblages of ceramic vessels dated to the 16th century from Pomerelian urban centres (Chojnice - after: Walenta et al., 2000: tab. 1; Walenta 2002: tab. 1; Debrzno, Człuchów distr. - Author’s unpublished research; Gdańsk - after: Trzeciecka and Trzeciecki 2002; Starski 2003; Lębork - after: Starski 2017: 238-239; Author's unpublished research; Puck - after: Starski 2016b: 238-239; 2019; Skarszewy, Starogard Gdański distr. - Author's unpublished research).

\begin{tabular}{|c|c|c|c|c|c|c|c|}
\hline \multirow[t]{2}{*}{ Town/Site/Phase } & \multirow[b]{2}{*}{ 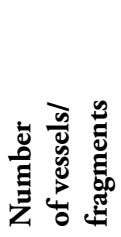 } & \multicolumn{6}{|c|}{ Types of wares (in \%) } \\
\hline & & 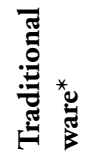 & 总 & 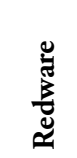 & 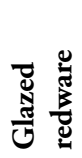 & के & 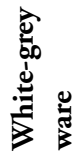 \\
\hline $\begin{array}{l}\text { Chojnice, Podmurna St., } \\
\text { 15th cent. (no. of fragm.) }\end{array}$ & 319 & 1,6 & 93,4 & 1,5 & 1,8 & 1,7 & 0,0 \\
\hline $\begin{array}{l}\text { Chojnice, Nowe Miasto } \\
\text { St., } 15 \text { th cent. (no. of } \\
\text { fragm.) }\end{array}$ & 732 & 2,7 & 94,4 & 1,2 & 1,1 & 0,6 & 0,0 \\
\hline $\begin{array}{l}\text { Chojnice, Nowe Miasto } \\
\text { St., first half of the 16th } \\
\text { cent. (no. of fragm.) }\end{array}$ & 836 & 3,1 & 90,6 & 3,2 & 2,5 & 0,6 & 0,0 \\
\hline $\begin{array}{l}\text { Debrzno, Market Sq. } 4 \text {, } \\
\text { second half of the } 16 \text { th } \\
\text { cent. (no. of fragm.) }\end{array}$ & 452 & 0,0 & 21,0 & 66,2 & 12,8 & 0,0 & 0,0 \\
\hline $\begin{array}{l}\text { Lębork, NE quarter of } \\
\text { the Market Sq., second } \\
\text { half of the 15th cent. } \\
\text { (no. of vessels) }\end{array}$ & 458 & 0,0 & 86,0 & 3,5 & 8,1 & 2,4 & 0,0 \\
\hline $\begin{array}{l}\text { Lębork, latrine on } \\
\text { Wyszyńskiego St., early } \\
\text { 17th cent. (no. of fragm.) }\end{array}$ & 706 & 0,0 & 12,4 & 43,3 & 44,3 & 0,0 & 0,0 \\
\hline
\end{tabular}




\begin{tabular}{|c|c|c|c|c|c|c|c|}
\hline \multirow[t]{2}{*}{ Town/Site/Phase } & \multirow[b]{2}{*}{ 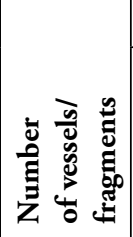 } & \multicolumn{6}{|c|}{ Types of wares (in \%) } \\
\hline & & 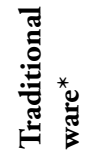 & 总 & $\underset{\mathscr{E}}{\stackrel{0}{\pi}}$ & 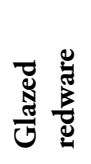 & के & 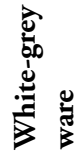 \\
\hline $\begin{array}{l}\text { Puck, second half of the } \\
15 \text { th cent. (structure in } \\
\text { general, no. of vessels) }\end{array}$ & 1514 & 5,2 & 64,1 & 5,2 & 18,5 & 3,5 & 3,5 \\
\hline $\begin{array}{l}\text { Puck, first half of the } \\
\text { 16th cent. (structure in } \\
\text { general, no. of vessels) }\end{array}$ & 2621 & 2,3 & 50,1 & 10,1 & 26,0 & 2,6 & 8,9 \\
\hline $\begin{array}{l}\text { Puck, town hall, early } \\
\text { 16th cent. (no. of vessels) }\end{array}$ & 1516 & 0,0 & 49,7 & 11,9 & 25,9 & 1,7 & 10,8 \\
\hline $\begin{array}{l}\text { Puck, pottery kiln half of } \\
\text { 16th cent. (no. of fragm.) }\end{array}$ & 1571 & 0,5 & 35,0 & 50,2 & 8,4 & 0,1 & 5,7 \\
\hline $\begin{array}{l}\text { Puck, pottery pile second } \\
\text { half of the 16th cent. } \\
\text { (no. of fragm.) }\end{array}$ & 1049 & 1,6 & 58,8 & 17,6 & 17,2 & 1,5 & 3,3 \\
\hline $\begin{array}{l}\text { Skarszewy, Market Sq., } \\
\text { second half of the 15th } \\
\text { cent. (no. of fragm.) }\end{array}$ & 174 & 0,0 & 74,7 & 16,1 & 8,6 & 0,6 & 0,0 \\
\hline $\begin{array}{l}\text { Skarszewy, Market Sq., } \\
\text { first half of the 16th cent. } \\
\text { (no. of fragm.) }\end{array}$ & 471 & 0,0 & 51,4 & 36,5 & 11,7 & 0,0 & 0,4 \\
\hline $\begin{array}{l}\text { Skarszewy, latrine on } \\
\text { Zduńska St., end of the } \\
\text { 16th cent. (no. of fragm.) }\end{array}$ & 646 & 0,0 & 12,7 & 61,3 & 25,7 & 0,0 & 0,3 \\
\hline $\begin{array}{l}\text { Gdańsk, Powroźnicza } \\
\text { St., second half of the } \\
\text { 15th cent. (no. of vessels) }\end{array}$ & 498 & 0,9 & 74,1 & 1,0 & 6,1 & 17,3 & 0,6 \\
\hline $\begin{array}{l}\text { Gdańsk, Powroźnicza } \\
\text { St., first half of the 16th } \\
\text { cent. (no. of vessels) }\end{array}$ & 336 & 0,0 & 53,0 & 2,9 & 29,8 & 12,0 & 2,3 \\
\hline $\begin{array}{l}\text { Gdańsk Szklary 4-5 St., } \\
15 \text { th cent. (no. of fragm.) }\end{array}$ & 464 & 0,0 & 78,9 & 6,4 & 7,2 & 6,7 & 0,8 \\
\hline $\begin{array}{l}\text { Gdańsk Szklary 4-5 St., } \\
\text { 16th cent. (no. of fragm.) }\end{array}$ & 627 & 0,0 & 55,9 & 6,9 & 23,8 & 9,1 & 4,3 \\
\hline
\end{tabular}

* - as a secondary deposit 
I4 $\mid$ Michat Starski

In effect, it may be stated that in the second half of the isth century, the pottery production and structure of goods used in particular urban centres was very similar (Tab. I). Most prevalent were flat-bottomed vessels fired in a reducing atmosphere, but there was also a noticeable increase in the percentage of pottery fired in an oxidising atmosphere (Walenta 2002: 44-45; Trzeciecka and Trzeciecki 2002: 155-156; Kościński 2003: 364; Starski 2016b: 204-206). This was linked to the spread of the glazing technique among local craftsmen, which is traceable since about the mid-I5th century. The composition of the ceramic mass also improved in the same period. Local ceramic goods formed the vast majority of those used, but the contribution of imported stoneware vessels amounted to several percent in the analysed towns (Tab. I). White-grey ware should also be considered a novelty, noted in small percentages at several sites and imported from outside Pomerelia (Starski 2013; 20I6b: 206-210).

There are slight differences in the structure and diversity of pottery forms between particular urban centres (Fig. 2; Tab. I). For instance, sites located in Gdańsk show a significantly greater share of glazed and stoneware vessels, exceeding IO\% (Trzeciecka and Trzeciecki 2002: 156-I57; Starski 2003; Kościński 2003: 364). Similar increased percentages are also traceable in some other towns, which may result from their proximity to the sea or to Gdańsk itself (e.g., in Puck, see Starski 2016b: 208-210). Unfortunately, it is currently impossible to determine the exact cause, due to the lack of data from other towns located near the main centre of the region and the low precision of dating of some artefacts. The morphological structure of the vessels shows also a decrease in the number of pots, which remain the most commonly-used form nevertheless, and an increase in bowls, jugs, and lids attesting to a growing diversification of household tableware (Starski 2016b: 190-194).

Despite the overall structure of pots and forms of vessels, the organisation and scale of handicraft production are still under-researched. Only two pottery workshops functioning in the second half of the Isth century have been identified so far (in Gdańsk and Skarszewy). The pace and nature of changes in pottery-making techniques (including glazing) in particular towns remains unknown, just as is the case concerning the number of craftsmen or the extent to which their production influenced other settlements. It seems that the increased intensity of relations with Polish lands traceable since the mid-Isth century had a certain impact on the trade in ceramic goods. This can be attested, for example, in regard to white-grey ware manufactured, among others, in Bydgoszcz and Płock (Starski 20I6b: 206-210). Finally, another poorlyresearched question is the adaptation of new ways in which these goods were used, especially in regard to individual consumption or the use of ceramic platters or plates. What also requires further elucidation is how the increasing availability of metalware and glassware impacted on the overall structure of kitchenware and tableware used in households as well as the competitiveness of particular ceramic products. 


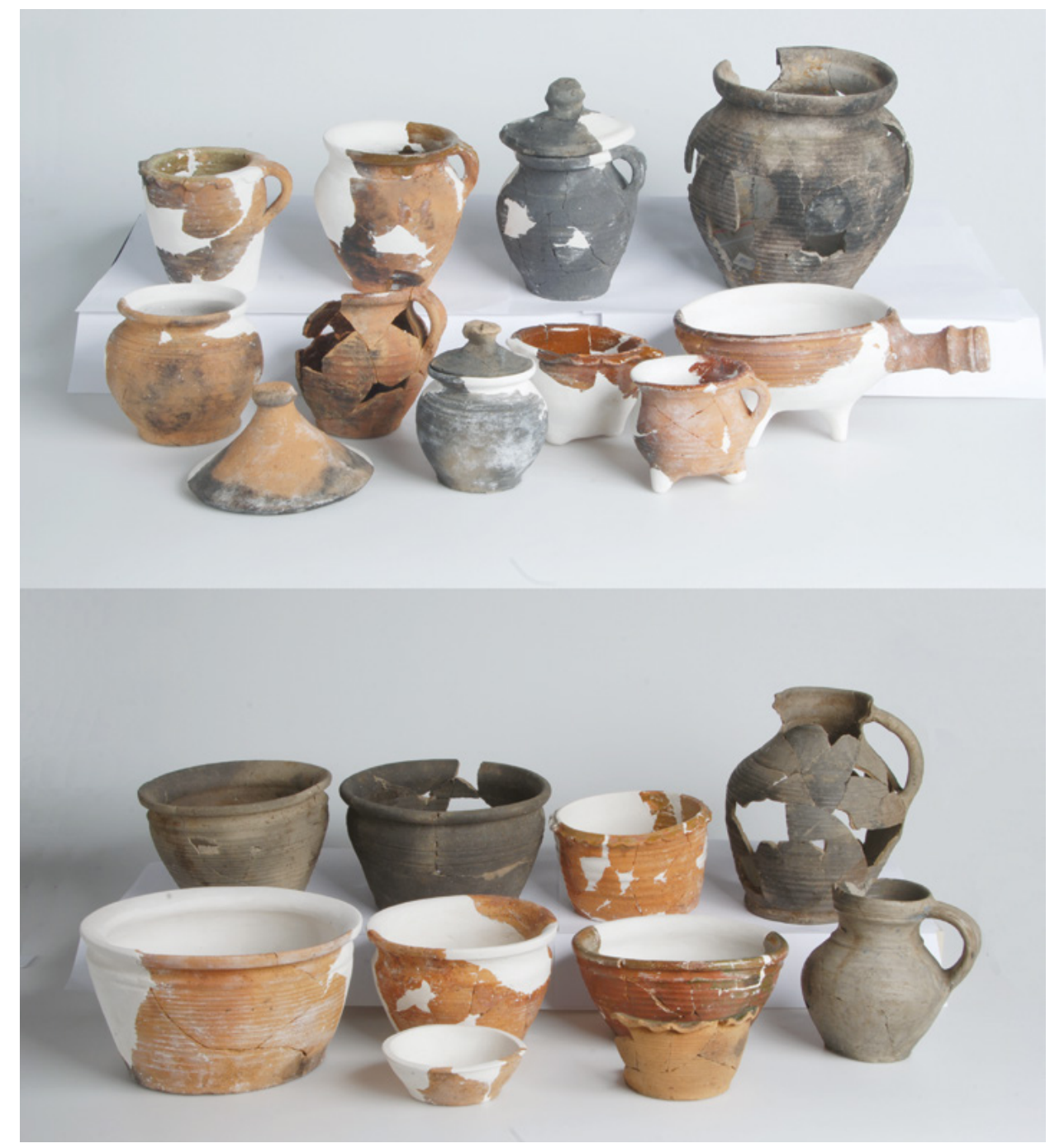

Fig. 2. Selected ceramic vessels from Puck from the end of the 15 th and early 16th centuries. Photo by M. Starski.

\section{WRITTEN SOURCES ON THE HISTORY OF POTTERY PRODUCTION}

The available written sources for the early-modern period enable the reconstruction of the scale of handicraft production in I6th-century Pomerelia. They do not, admittedly, cover the whole period under discussion but still provide data allowing assessment 
I6 $\mid$ Michat Starski

of the number of potters and thus - the manufacturing output of particular urban communities. Royal inspections from the years 1564-1565 (Hoszowski 196I) and the fiscal register of 1570 (Źródta dziejowe 19II: 98-288), despite certain shortcomings of these documents, roughly illustrate the number of potters active in Pomerelia in the third quarter of the i6th century. Apart from that, other municipal sources are available that shed light on the craftsmen's guilds and regulations concerning distribution of goods in some of the investigated towns.

For most of the towns from the third quarter of the i6th century, the aforementioned sources recorded from one to four potters (Fig. 3), while in several rare cases (Świecie, Tczew, Tuchola) from six to twelve craftsmen were mentioned (Gierszewski 1966: 202-203). Again, Gdańsk stands out in that regard, with a potters' guild registered for the first time already in 1374 . In the early I5th century, there were 17 potters active in the town, which dropped to Io in the year 1526. In turn, at the end of the 16th century and in the first half of the i7th century, municipal sources mentioned names of is craftsmen of this specialty. Isolated accounts from the same time inform about journeymen, thus allowing for a tentative assumption that the local workshops were rather small. Hence, the scale of their production was in all probability comparably

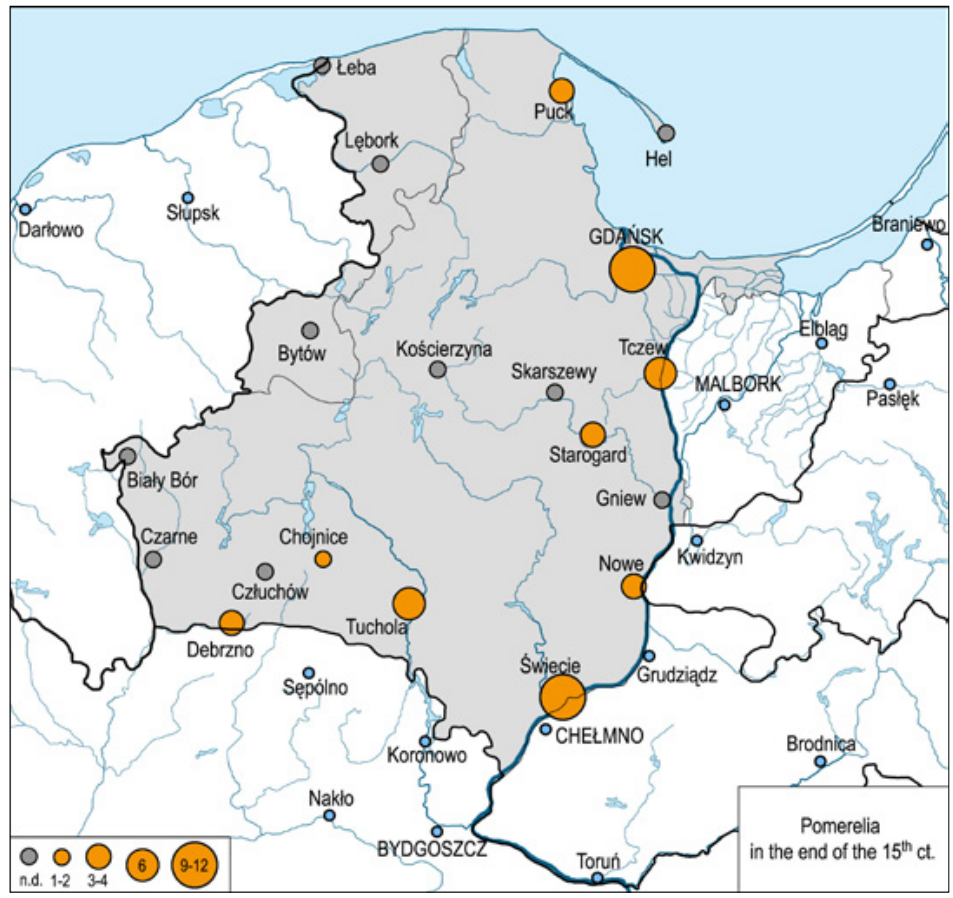

Fig. 3. Number of potters registered in Pomerelian urban centres in 1570. Prepared by M. Starski. 
modest. Simultaneously, data available for the 16 th, as well as the 17 th, centuries show that Gdańsk saw a significant inflow of external goods produced regionally, which prompted some of the Gdańsk craftsmen to requalify into producing stove tiles or glazed vessels (Bogucka 1962: 156-157). On the other hand, data on the potters' guilds operating in smaller towns of the region are very limited. It may be supposed that accounts mentioning three to four potters for some of the towns reflect the functioning of craftsmen's fraternities (e.g., in Puck), whereas smaller numbers should be connected with multi-craft associations.

In the light of the above data, it may be stated that pottery-making could be traced in most of the urban centres in the discussed period. This information arouses questions regarding the scale and character of this production. In the majority of the towns, potters most likely catered for the local markets, as there were few active craftsmen. In the cases of Swiecie, Tczew, and Tuchola, the number of craftsmen certainly exceeded local needs, and thus it may be supposed that production in these localities was geared towards external trade. The same is true for Gdańsk's potters who specialised in manufacturing stove tiles and glazed vessels. It is, therefore, possible to hypothesise that there existed regional centres specialised in pottery production. However, this supposition would require verification by future studies.

\section{DISCUSSION}

\section{Source basis for the research}

Compared to the material described above, the source base enabling characterisation of Pomerelian pottery-making in the I6th century is only slightly less voluminous, but it has certain shortcomings. The largest assemblage of finds comes from Gdańsk. It is necessary to note, for example, recently-published finds from Szeroka Street near the Dominican church (Trzeciecka and Trzeciecki 2002; Oniszczuk-Rakowska 2002; Dąbal and Szczepanowska 20I8), the vicinity of the Green Gate (Kościński 2003), the housing quarter on Powroźnicza Street (Starski 2003), the Wisłoujście fortress (Dąbal 20I5), and Lastadia (Kościński 2020). Many artefacts have also been obtained from the chartered town and the castle site in Puck (Starski 2009; Kruppé and Milewska 20I4; Starski 20I5; 20I6b); slightly fewer finds have been discovered in investigations in Chojnice, in the market square, on Nowe Miasto Street, 3I Stycznia Street, and near the Jesuit College (Walenta et al., 2000; Garas and Trzciński 20I0: 19-29; Trzciński 20II: I03-IO7); finally, two smaller assemblages come from the north-eastern quarter of housing adjoining the market square and on Wyszyńskiego Street in Lębork (Starski 2017). Therefore there is a representative basis for attempting a synthetic perspective on pottery use in these urban centres. For the remaining I4 towns in the region, only a few have been subjected to investigations, but the material from them 
is as yet unpublished or no I6th-century finds have been obtained Człuchów - two excavated urban plots and the castle site, ${ }^{1}$ Debrzno - plots in the southern frontage of the market square, ${ }^{2}$ Gniew - market square, ${ }^{3}$ Skarszewy - excavations within the former mid-market-square housing block (Starski 20I8) and finds from Zduńska Street, ${ }^{4}$ Tczew - vicinity of Chopina Street (Kochanowski 1995); and Tuchola - Starofarna Street (Kmieciński and Nowakowski 1978). For the others, no precise information is available. The above-mentioned studies and publications are, therefore, obviously valuable for investigation of the matters discussed here, but they shed light only on select areas within the investigated urban centres. This is a major hindrance for drawing conclusions about the entire region of Pomerelia. Nevertheless, the existing evidence allows the formulation of preliminary observations. As a side note to the aforementioned data on ceramic vessels, it is also necessary to mention finds of stove tiles that provide a backdrop for the present discussion. A relatively rich assemblage of renaissance stove tiles (up to several hundred) comes from Chojnice, Debrzno, Gdańsk, Lębork, Puck, and Skarszewy (Starski 202I).

As per the above review, the previous scholarship concerning I6th-century pottery from the investigated province amounts to about a dozen studies and publications dedicated to moveable finds. Many of them reflect their authors' interest in latemedieval artefacts, the youngest of which are sometimes dated to the early or mid-I6th century. Such was the case for the finds from Chojnice, Gdańsk, Lębork, and Puck. A characteristic of another group of assemblages is formulated through the analysis of early-modern finds dated to between the 16th and i8th centuries. These publications deal with finds obtained in Gdańsk and smaller towns (Oniszczuk-Rakowska 2002; Garas and Trzciński 2010: 19-29; Dąbal 20I5; Starski 2015: II4-I20). Some attention has also been paid to the discussion of imported glazed vessels, stoneware, and whitegrey ware (Starski 2013; Dąbal 2020). The structure of pottery-making in the 16th century, approached as a separate problem, has so far been addressed in only a single publication which presented the preliminary results of the discovery of a potter's workshop in Puck dated to the second half of the I6th century (Starski 2019). It is difficult not to get the impression, however, that the deeper one goes into the I6th century, the fewer phenomena can be considered certain, especially as compared to the turn between the late-medieval and early-modern periods.

Hence, when addressing the question of production and assortment of goods used in Pomerelian towns in the I6th century, one has to characterise the crucial research areas relevant to studies on manufacturing techniques, the structure of production,

Compiled by the author.

Unpublished research results compiled by M. Miścicki.

Unpublished compilation of ceramic finds by E. Choińska-Bochdan and W. Pela.

Unpublished preliminary compilation of research results by K. Blusiewicz. 
the assortment of goods used, and, in effect, also the chronology of innovations. The organisation of production, including the trading and importing of foreign goods, will be discussed as yet another separate issue. Such a perspective on the subject matter will, therefore, require considering differences between particular towns, including Gdańsk. This way, it will be possible to outline the process of transformation in the investigated area in the early-modern period. In terms of chronology, the present discussion spans the period from the early i6th to the beginning of the i7th centuries, since some of the younger assemblages of finds are dated to the turn of these periods. The geographical scope of the study is defined by the borders of the Pomeranian Voivodeship of the First Polish-Lithuanian Commonwealth.

\section{Changes in pottery production techniques and processes}

Previous studies on I6th-century pottery from Pomerelia have only briefly addressed the question of pottery production techniques. Issues related to, for instance, vessel forming techniques or composition of ceramic masses have remained largely unexplored, with only slightly more data on changes in frequencies of different types of vessels in particular manufacturing traditions.

The available information regarding the situation at the end of the late Middle Ages allows to assume that at the turn of the I5th and I6th centuries, vessels were formed by coiling and smoothing on a potter's wheel. Such a conclusion stems from an analysis of the vessels from Puck (Starski 20I6b: II9-I24; 20I9: IIO-II3), that show significant similarities to finds obtained, for example, from Chojnice, Lębork, Skarszewy, and Gdańsk (Trzeciecka and Trzeciecki 2002: 138-I39; Starski 2003; 2017: 240). This would indicate that there had not been any major changes in pottery production technique in the investigated period. At the same time, the composition of the ceramic mass improved visibly, which was especially true for glazed redware and achieved through adding a small amount of fine-grained admixture. Finds dated to subsequent decades, for example from Chojnice, Debrzno, and Lębork (north-eastern housing quarter adjoining the market square) show the same characteristics and indicate that the manufacturing techniques detectable at the beginning of the 16th century did not change at least until the mid-I6th century. The same situation was reflected by finds from Gdańsk from investigations in Powroźnicza Street and those from the vicinity of the Dominican church (Trzeciecka and Trzeciecki 2002; Starski 2003). Similar data were obtained in Puck from a potter's workshop dated to the mid-I6th century (Fig. 4). Compared with such material, assemblages from between the fourth quarter of the I6th and early 17 th centuries stand out. These include finds from a latrine in Wyszyńskiego Street in Lębork (Fig. 5), Zduńska Street in Skarszewy, and an urban plot adjoining the market square in Debrzno (Fig. 6), as well as I6th-century assemblages from Powroźnicza Street and the Green Gate in Gdańsk (Oniszczuk-Rakowska 2002; Kościński 2003). In all these places, apart from the improved quality of the 


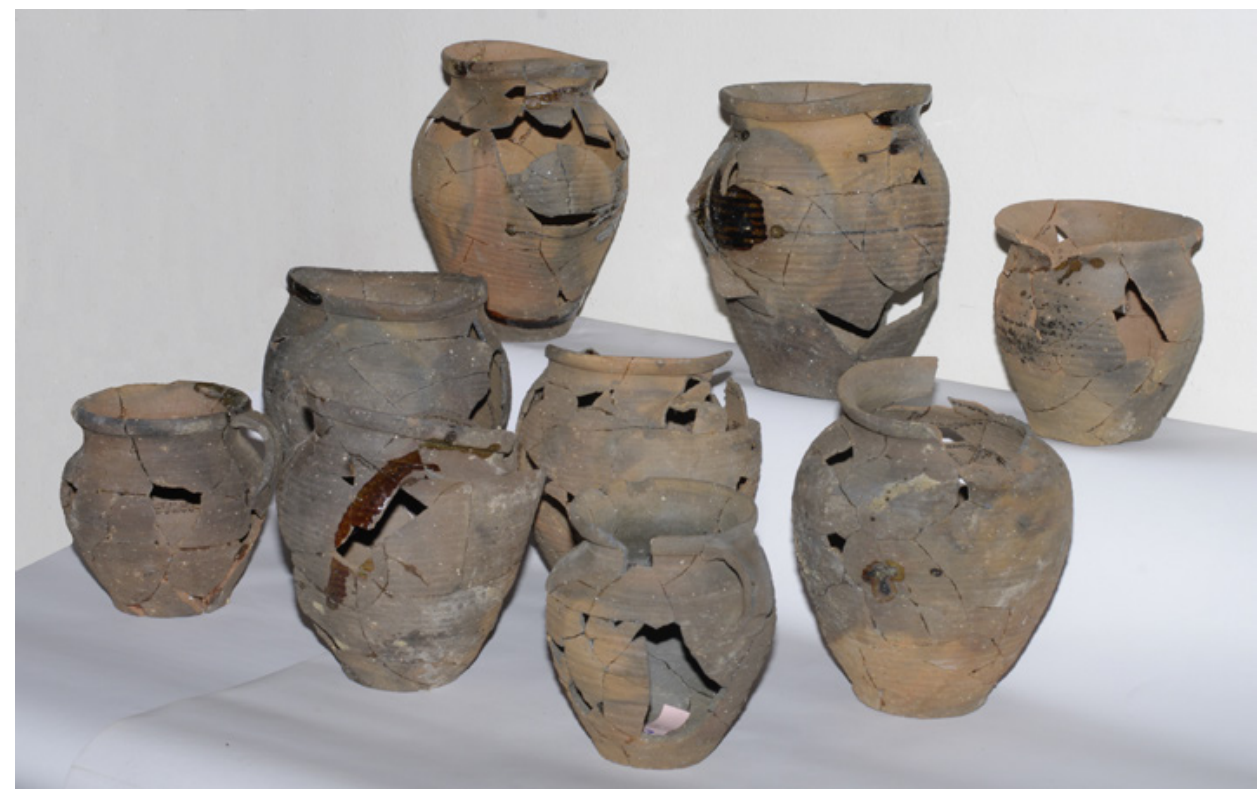

Fig. 4. Selected ceramic vessels from the pottery kiln from Puck, dated to the mid-16th century. Photo by M. Starski.

ceramic fabrics, the walls of the vessels were noticeably thinner and of more delicate structure, which corroborates the hypothesis that the techniques of pottery production had changed. This, in turn, would imply that wheel-throwing was used by the time. The fact that the use of this technique has been confirmed in several places may be considered plausible proof of its being known and used in other urban centres of Pomerelia. It is necessary to remember that the ceramic products market was highly integrated and that the guild structures functioning at the time required aspiring craftsmen to travel and gain practical experience, and this fostered the rapid spread of adaptations or innovations in manufacturing techniques (Tandecki 1986: 276-280). However, the exact moment of the increase in frequency of the use of wheel-throwing is hard to pin-point. On the basis of the currently available data, an approximate time-frame for this process should be determined to have lain between the middle and the end of the i6th century.

Whereas changes in pottery production techniques and preparation of raw materials are traceable since the mid-I6th century, the gradual transformations in the structure of the produced vessels can be noticed already at the end of the Isth and throughout the I6th centuries (Fig. 2). The latest research suggest that glazing and the use of an oxidising firing atmosphere were adopted in local production already around the 
Continuation or Evolution? Changes in Pottery Production... $\mid 2 I$
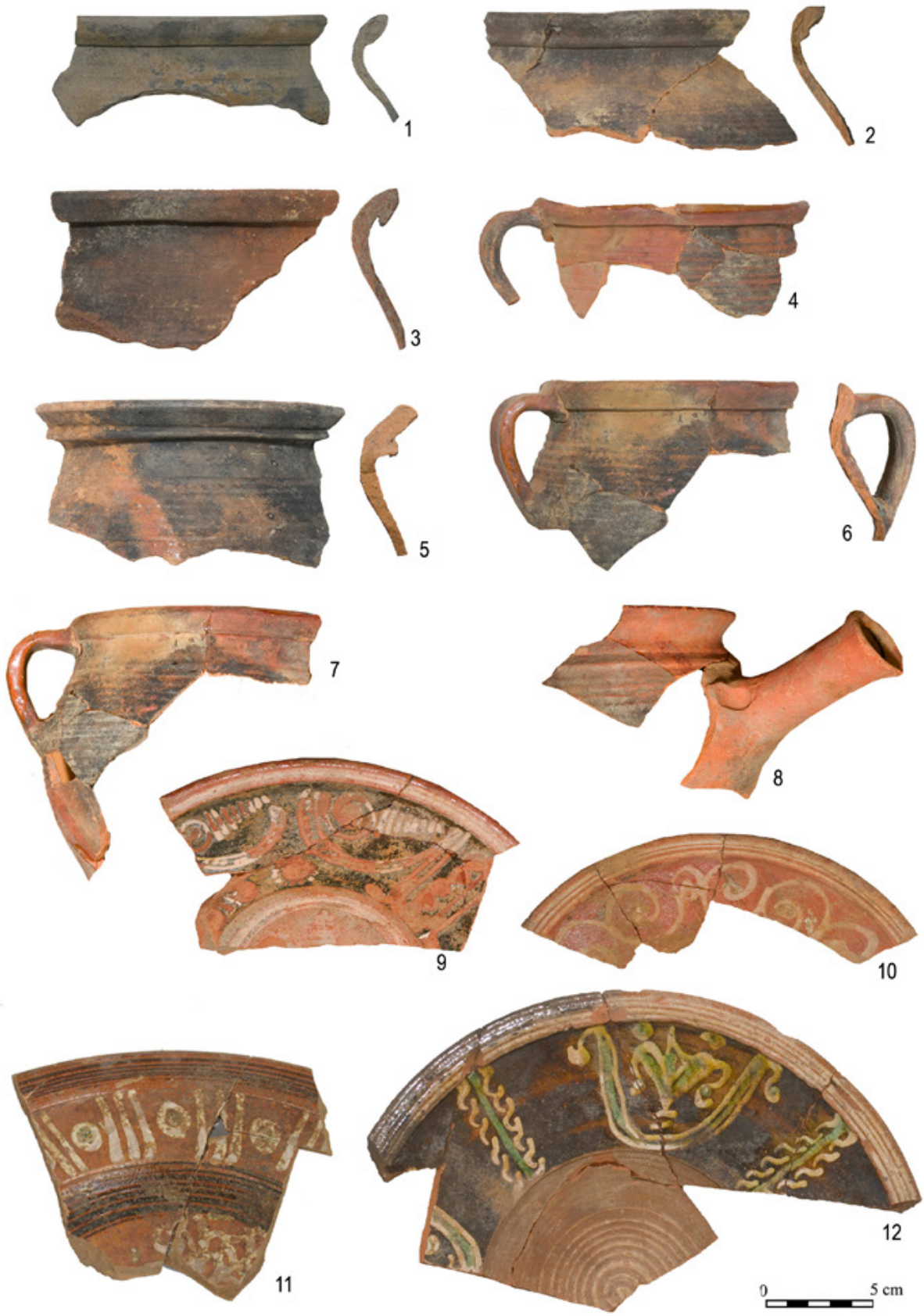

Fig. 5. Selected ceramic vessels from the cesspit at $S$. Wyszyńskiego Street in Lębork, dated to the end of the 16th century (1-8 - pots and grapens; $9-12-$ plates). Photo by M. Starski. 
$22 \mid$ Michat Starski

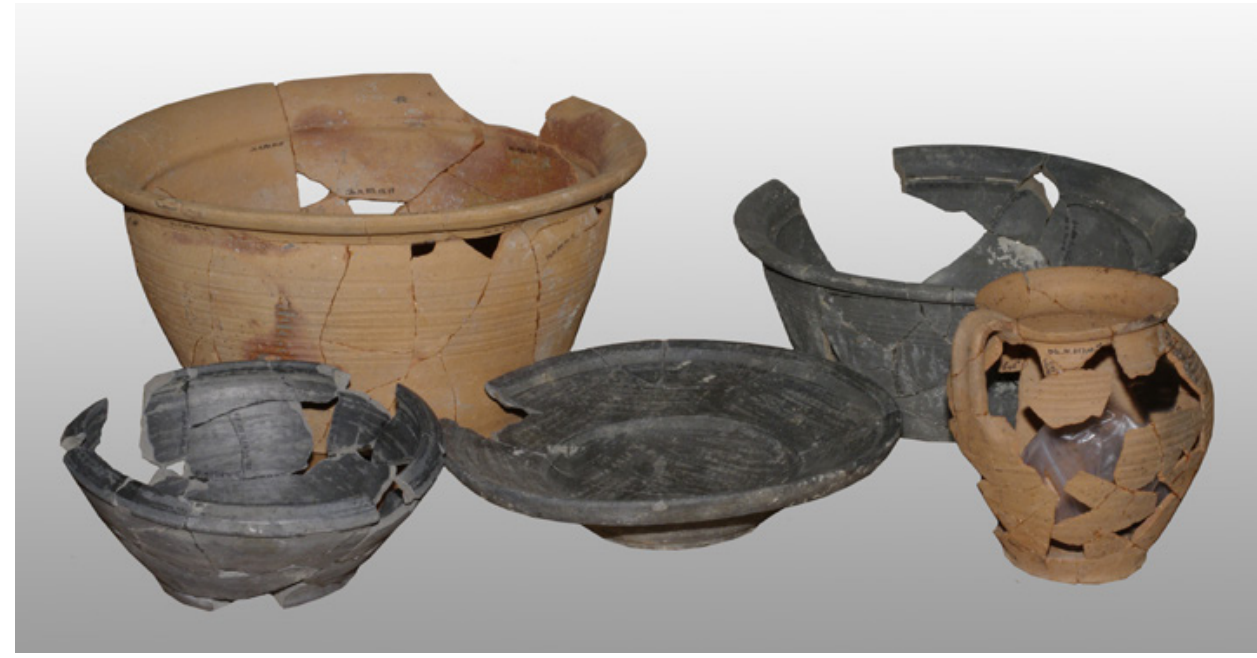

Fig. 6. Selected ceramic vessels from the pit within the urban plot adjoining the market square in Debrzno, dated to the second half of the 16th century. Photo by M. Starski.

middle of the I5th century. A certain number of such vessels have been registered in Chojnice, Gdańsk, Lębork, Puck, and Skarszewy in layers dated to the third quarter of the I5th century (Trzeciecka and Trzeciecki 2002: I55-156; Kościński 2003: 364; 2020: 30-36; Starski 20I6: 204-206; 20I7: 24I-242). Their frequency typically amounts to about a dozen percent, reaching $20 \%$ in Gdańsk and Puck in the first quarter of the I6th century (Tab. I). However, it remains unknown how firing in an oxidising atmosphere spread in the subsequent decades of the I6th century. The assemblage obtained from the potter's kiln in Puck dated to the mid-i6th century is not entirely representative in that regard, as it is smaller than other production sites and most likely reflects a single batch of pottery (Starski 2019). It cannot be denied, on the other hand, that it was designed to produce an oxidising atmosphere and fire redware (Fig. 4). This type of vessels is also prevalent in the vicinity of the workshop, in what is interpreted as a heap of discarded products. It is noteworthy that the majority of these vessels were not glazed, with glazing preserved on less than 20\% (Starski 20I9: IIO-III). Analogous data were provided by slightly less numerous assemblages from a latrine on Wyszyńskiego Street in Lębork, a cesspit on Zduńska Street in Skarszewy, and the refuse dumping pit in an urban plot in the southern frontage of the market square in Debrzno (Tab. I; Fig. 6). ${ }^{5}$

Unpublished research by the author. 
This information indicates that the use of an oxidising atmosphere became common in pottery-making and its frequency in the structure of products increased gradually to reach about $50-70 \%$ in the second half of the i6th century. The percentage of glazed ware would also rise, but did not exceed about $30 \%$ in the assemblages from the period, with the remaining oxidised pottery unglazed (Tab. I). The percentage of vessels fired in a reducing atmosphere was lower (about 30-40\%). In the case of the potter's workshop from Puck, this type of firing was attested only for pots and bowls, with similar data obtained from the aforementioned sites at Debrzno, Lębork, and Skarszewy. This situation seems to reflect a diversity of firing techniques and, thus, also different manufacturing traditions and the diversity of goods available in the market. This seems to be a consequence of differential supply, encompassing cheaper and more expensive vessels as well as a wide array of products. It would implicitly indicate an increased market demand and, in effect, this would encourage diversification of produced goods. The introduction of more expensive products (most likely glazed vessels) may have also been an attempt at competing with metalware that was gaining in popularity among householders. On the other hand, ceramic vessels would still be indispensable in numerous everyday tasks, such as storage or other housekeeping activities.

\section{Assortment of products}

In comparison with the difficulties related to observing evolution in pottery production techniques, changes in assortments of used goods are relatively easier to trace. The evidence (i.e., analysis of ceramic assemblages), is admittedly exactly the same as previously, but new forms of vessels are attested already at the end of the late Middle Ages and the first half of the i6th century. This allows the identification of a trend in changes regarding the forms of vessels and the structure of assemblages.

Since the decline of the late Middle Ages, the percentage of pots dropped from about $50-70 \%$ at the end of the 15 th century to $40-60 \%$ in the first half of the 16 th century (Tab. I). Data for the second half of the latter century are known only from several sites, but they seem to reflect further decrease in the contribution of these vessels to about $40-50 \%$. The pots seem also to have become more diverse in terms of sizes. Greyware and redware pots were medium and large, whereas glazed redware ones were usually medium and small (Trzeciecka and Trzeciecki 2002: I46-I48; Starski 2016b: 190-193). The shapes of these vessels underwent a certain evolution too. The ratio between the diameters of bases and mouths increased, with the bases being smaller. Flat-bottomed vessels were still a staple, characterised by the greatest circumference of the body being located in the upper part, often above the two thirds of the height, which made them appear more slender. Among the glazed redware pots, slender shapes as well as tripod forms were more popular, typically with a shorter distance between the shoulder and rim, and often lacking necks (Trzeciecka and Trzeciecki 2002: I46-I48; Kościński 2003: 367; Starski 2003; 2016b: 190-193). 
Greater popularity seems to have been enjoyed also by bowls, which comprised about $20 \%$ of assemblages (Tab. I). They came in a variety of types and sizes. Such a diversity stemmed from their different uses within households, including housekeeping, cooking, and eating (Fig. 6). Hence, a group could be distinguished that consists of large and very large greyware and redware vessels, both rare in the I4th and I5th centuries. They may have been used in housekeeping as well as for kitchen-related purposes, often replacing pots as food-storage containers. The percentage of smaller bowls also rose, with examples of glazed redware being most common. Their ornamentation and surface finishing technique indicate that they were intended as tableware.

The frequency of jugs changed only slightly, however, their shapes and sizes did evolve (Tab. I). Greyware vessels polished across their entire surfaces were replaced by specimens in which polishing took the form of a geometrised or symbolic ornament. This category of vessels included small, medium, and large examples. They were typically of spherical shapes with clearly-defined feet or moulded bases. A group of glazed jugs were also identified, usually small or medium-sized, but their frequency was marginal among I6th-century specimens. Pans, on the other hand, were more common than in the late-medieval period (Tab. I). Their frequency had never been great, due to their specific function, but they were present in the majority of the discussed assemblages, which testifies to their common use in the investigated I6thcentury urban centres (Trzeciecka and Trzeciecki 2002: 150; Kościński 2003: 366-367; Starski 2003; 2016: 194).

A new type of vessel were plates and platters. Only single specimens of these types were found in late-medieval contexts, whereas in layers dated to the second quarter and the second half of the 16th century, this group made up almost $10 \%$ of vessels (Trzeciecka and Trzeciecki 2002: 150-151; Kościński 2003: 366-367; Starski 2017). Their increased frequency results from changes in food consumption habits among the Pomerelian burghers who would prefer to eat from separate receptacles distributed to individual people at the table. The same custom and popularity of plates and platters could be seen in West-European urban centres, especially in Germany and the Netherlands. Some of the plates were probably of local provenance, but others were imported from the United Provinces of the Netherlands or the basin of the Werra and Weser rivers, which were known centres for production of painted plates and platters (Stephan 198I; 1992; Oosten 2009; Amsterdam ceramics 20I2). The remaining types of vessels showed little change, but not much can be said about them due to their low frequencies of occurrence. It is plausible to say that the percentage of mugs increased, together with the appearance of new forms equipped with lugs and having proportions similar to cups. The number of goblets, shallow bowls, and roasting pans was also noticeable (Trzeciecka and Trzeciecki 2002: 174-I8I; Starski 20I6b: 188-I89).

In the light of the above, it seems that the character of changes in the assortment of goods used in the I6th century does not reflect a major transformation of households 
but rather the gradual introduction of innovations. These changes stemmed not only from differences in the structure of the ceramic products used but also from increased frequency of metalware and glassware. The former replaced pots as common all-purpose household vessels. It seems that the use of cauldrons for cooking entailed greater demand for bowls for kitchen and housekeeping purposes other than heating up food over fire. The frequency of table bowls, platters, and plates suggests that these vessels were also often used as a component of a household's tableware. The observed changes provide one more significant insight. They were related to the evolution of food consumption habits across Europe and are testimony of the adaptation of cultural patterns in Pomerelian households (Verhaeghe 1997; Oosten 2009; Blažková 20I3; Španihel 20I4; Blažková and Žegklitz 20I6). This process was most evident in Gdańsk (Oniszczuk-Rakowska 2002: 198-205), but each of the assemblages obtained from smaller townships would support similar conclusions. Hence, this illustrates the rapid spread of these, apparently attractive, new models of consumption even in the smaller urban centres of the region.

\section{CONCLUSIONS AND ORGANISATION OF TRADE}

The analysis of the evidence performed here for I6th-century Pomerelian potterymaking is certainly insufficient to enable an authoritative summary of the changes occurring in the investigated period. The preliminary conclusions seem to merely reveal the main trends, leaving numerous questions open for further research.

The presented characteristic of the finds indicates that the trajectories of change traceable at the end of the late Middle Ages continue into the I6th century. This is true, for instance, in regard to the quantities of unglazed and glazed redware vessels present. Their greater frequency enriched the assortment of goods available, since certain types of pottery were fired only with particular techniques. The structure of vessel usage shows a decrease in the frequencies of pots and an increase in other forms. However, this tendency cannot be considered a novelty but rather a successive and slow trend related to improvements in quality and a diversification of production. The rare actual innovations would include the increase in popularity of white-grey ware imported from centres operating within the Kingdom of Poland and the spread of plates and platters used for individual consumption.

A proper overview of the above trends requires referring to the cultural changes and market mechanisms functioning in the I6th century. Increasing diversification of the ceramic market was, on the one hand, a defensive mechanism and pressure exerted on potters by producers of vessels made of other materials (metal and glass), which resulted in improved competitiveness against other craftsmen. On the other hand, such competition would not have been possible without a shift in the needs of 
consumers who preferred to buy other products and gather richer assortments of vessel types (Verhaeghe 1997: 31; Oosten 2009: I4; Blažková 2013: 220-22I; Španihel 20I4: I54-I55; Blažková and Žegklitz 2016: I48-163). This was true for both higher-quality vessels used for food consumption and cheaper ones intended for daily housekeeping purposes. Such diversification impacted the assortment of products available for sale, among which the glazed ones were undoubtedly more expensive than greyware or unglazed redware. This was also connected to an enriched repertoire of forms, i.e., a greater number of large pots and bowls, both greyware or redware, used in a variety of ways.

Beyond doubt, the diversification of pottery has one more important aspect. It certainly indicates a different kind of participation of customers in shaping the market. This is evident in the analysed assemblages, which are heterogeneous even within single urban centres. This is most likely a reflection of economic differences but also, potentially, distinct modes of cultural participation and a heterogeneity of customer needs. It may also be perceived as a difference in consumer attitudes and strategies. This phenomenon is, obviously, constantly at play in developed societies, including urban communities, but in the late Middle Ages, with a lower level of wealth and narrower range of goods offered by craftsmen (largely restricted to greyware), the differences in assortment of goods were a result of a limited number of factors (e.g., the presence of imported stoneware or glazed redware).

It is clear, therefore, that pottery-making and the market for ceramic goods in I6th-century Pomerelia reflected diverse consumer attitudes and an increase in expectations coupled with greater spending power. The producers could provide buyers with a morphologically and technologically (and thus functionally) diverse selection of products. An important factor in this process was also the cultural influence of West-European burghers on Gdańsk and, indirectly, on the smaller townships of the region (Gaimster and Nenk 1997; Verhaeghe 1997; Gaimster 2006; Oosten 2009).

The issue of the production capacity of urban potters in Pomerelia require a separate commentary. Undoubtedly, this question has so far been least investigated. The observations outlined above inevitably lead to the conclusion that pottery-making centres functioned in Pomerelia, the productions of which would reach beyond their direct vicinity and circulate in the regional market. As a matter of fact, this possibility has already been proposed for pottery-making in other Polish towns as a factor that shaped their range of influence in similar ways (Kwapieniowa 1976). Although such regionally important centres have not been identified for the discussed province, based on the numbers of potters active in particular smaller towns, it seems that this category would likely include Świecie, Tuchola, and Tczew, as in each of these centres between 6 to 12 potters were registered in the third quarter of the i6th century (Źódta dziejowe 19II: 98-288). A similar role was also played by Gdańsk, where more than a dozen ceramic craftsmen were active at the time. Given the population size of the 
whole agglomeration, it is probable that the local products found buyers locally. The only exception would be stove tiles, which were exported to other towns throughout the Commonwealth (Pospieszna 2009).

The above conclusions are still within the realm of research hypotheses. This applies equally to the structure of the changes, the characterisation of particular consumer attitudes, and the attempts at identification of local pottery-making centres undertaken by archaeologists. Thus, there is a clear need for further studies in regard to the transformation of the potter's craft in this part of early-modern Poland.

\section{REFERENCES}

Amsterdam ceramics 20I2. Catalogue of archaeological ceramics from Amsterdam II75-20II. In J. Gawronski (ed.), Amsterdam ceramics. A city's history and archaeological ceramics catalogue II75-20II, I03-312. Amsterdam.

Biskup, M. 1980. Rozwój sieci miast pruskich do drugiej połowy XVII w. Kwartalnik Historii Kultury Materialnej 28(3): 40I-4I2.

Blažková, G. 20I3. Vývoj raně novověké kuchyňské a stolní keramiky v Čechách na základě souborů z Pražského hradu. Památky Archeologické I04: 183-230.

Blažková, G. and Žegklitz, J. 20I6. Současný stav poznání raně novověké keramiky v Praze. Archaeologica Pragensia, Supplementum 3: 147-178.

Bogucka, M. 1962. Gdańsk jako ośrodek produkcyjny w XIV-XVII wieku. Warszawa.

Bogucka, M. and Samsonowicz, H. 1986. Dzieje miast i mieszczaństwa w Polsce przedrozbiorowej. Wrocław.

Czaja, R. 2000. Miasta i ich posiadłości ziemskie w państwie zakonu krzyżackiego w Prusach. In Z. H. Nowak and R. Czaja (eds), Państwo zakonu krzyżackiego w Prusach. Podziaty administracyjne $i$ kościelne $w$ XIII-XVI wieku, 45-65. Toruń.

Dąbal, J. 20I5. Wyroby ceramiczne. In J. Dąbal, K. Krawczyk and T. Widerski (eds), Gdańsk, Twierdza Wistoujście. Badania archeologiczno-architektoniczne w latach 20I3-20I4, 22I-264. Gdańsk.

Dąbal, J. 2020. Naczynia kamionkowe z Kolonii i Frechen z gdańskiej Lastadii. In B. Kościński (ed.), Lastadia. Najstarsza stocznia gdańska w świetle badań archeologicznych. Archeologia Gdańska 7, 299-310. Gdańsk.

Dąbal, J. and Szczepanowska, K. 20I8. W spiżarni, kuchni i na stole - naczynia i sprzęty domowe w domach mieszczańskich. In J. Dąbal (ed.), Domy i ich mieszkańcy w świetle badań archeologicznoarchitektonicznych przy ulicy Świętojańskiej 6-7 w Gdańsku, I67-20I. Gdańsk.

Gaimster, D. 2006. The historical archaeology of pottery supply and demand in the Lower Rheinland AD I400-I800. An archaeological study of ceramic production, distribution and use in the city of Duisburg and its hinterland. Oxford, British Archaeological Reports International Series I5I8. Studies in Contemporary and Historical Archaeology I.

Gaimster, D. and Nenk, B. 1997. English households in Transition c. I450-1550: the ceramic evidence. In D. Gaimster and P. Stamper (eds), The Age of transition. The archaeology of English culture I400-I600. Proceedings of a conference hosted by the society for Medieval Archaeology and the society for Post-Medieval Archaeology at the British Museum London I4-I5th November 1996, 171-195. Oxford. 
Garas, M. and Trzciński, Ł. 20Io. Badania archeologiczne na dziedzińcu Kolegium Jezuickiego w Chojnicach. Zeszyty Chojnickie 25: II-44.

Gierszewski, S. 1966. Struktura gospodarcza i funkcje rynkowe mniejszych miast województwa pomorskiego $w X V I$ i $w$ XVII $w$. Gdańsk.

Grzegorz, M. 1988. Lokacja miast na Pomorzu Gdańskim w latach I309-I454 na tle działalności politycznej i gospodarczej oraz administracyjnej zakonu krzyżackiego. In M. Biskup (ed.), W kręgu stanowych i kulturalnych przeobrażeń Europy Pótnocnej w XIV-XVIII w., 39-55. Toruń.

Grzegorz, M. 2007. Pomorze Gdańskie pod rzadami Zakonu krzyżackiego w latach 1308-I466. Bydgoszcz. Hoszowski, S. (ed.). 196r. Lustracja województwa pomorskiego 1565. Gdańsk.

Kmieciński, J. and Nowakowski, A. 1978. Badania archeologiczno-architektoniczne w Tucholi w latach 1970-1972. Komunikaty Archeologiczne 2: 315-325.

Kochanowski, M. 1995. Z nowych odkryć archeologicznych na obszarze Starego Miasta w Tczewie. Pomorania Antiqua I6: 299-325.

Kościński, B. 2003. Badania w obrębie średniowiecznego Portu Gdańskiego (stan. I03 - Zielona Brama w Gdańsku). In H. Paner and M. Fudziński (eds), XIII Sesja Pomorzoznawcza, vol. 2, 357-383. Gdańsk.

Kościński, B. 2020. Podstawy chronologii stanowiska. In B. Kościński (ed.), Lastadia. Najstarsza stocznia gdańska w świetle badań archeologicznych. Archeologia Gdańska 7, 27-54. Gdańsk.

Kruppé, J. and Milewska, M. 20I4. Dzieje zamku w Pucku. Warszawa.

Kwapieniowa, M. 1976. Organizacja produkcji i zbytu wyrobów garncarskich w Krakowie w XIV-XVII w. In M. Kwapień, J. Maroszek and A. Wyrobisz (eds), Studia nad produkcją rzemieślniczq w Polsce (XIV-XVIII w.), Studia z dziejów rzemiosła i przemysłu 30, 7-85. Warszawa-Wrocław-KrakówGdańsk.

Oniszczuk-Rakowska, A. 2002. Ceramika nowożytna z latryn posesji przy ulicy Szklary 2-5 w Gdańsku. In A. Gołembnik (ed.), Dominikańskie Centrum św. Jacka w Gdańsku. Badania archeologiczne. Vol. 2., 207-272. Warszawa, Światowit. Supplement Series P: Prehistory and Middle Ages 9.

Oosten, van R. 2009. Changes in the Dutch archaeological ceramic record in the period I300-I700: the reflection of a 'ceramic (consumer) revolution' or innovation in local craftsmanship. Urbanization and Urban Culture, I-36. Groeningen.

Pospieszna, B. 2009. Naśladownictwa kafli gdańskich i pomorskich w głębi Rzeczypospolitej. In J. Kriegseisen (ed.), Rzemiosto artystyczne w Prusach Królewskich, 62-83. Gdańsk.

Ptaszyński, M. 20I8. Reformacja w Polsce a dziedzictwo Erazma z Rotterdamu. Warszawa.

Španihel, S. 20I4. Stredoveká a novoveká keramika severozápadného Slovenska. Študijne Zvesti Archeologickeho Ustavu SAV 55: I4I-I8I.

Starski, M. 2003. Późnośredniowieczne naczynia ceramiczne z badań archeologicznych przy ul. Powroźniczej na Gtównym Mieście w Gdańsku (typescript in the Archives of the Faculty of Archeology of the University of Warsaw).

Starski, M. 2009. Późnośredniowieczne naczynia gliniane z zamku w Pucku. Studia i Materiaty Archeologiczne 14: 195-284.

Starski, M. 20Io. Uwagi o późnośredniowiecznej wytwórczości garncarskiej na Pomorzu Gdańskim. Archaeologia Historica Polona 18: 57-74.

Starski, M. 20I3. Naczynia białoszare w Pucku i na Pomorzu Gdańskim - rodzime czy obce. Próba identyfikacji jednego z nurtów późnośredniowiecznej wytwórczości garncarskiej. Archaeologia Historica Polona 21: 187-208. 
Starski, M. 20I5. Rynek miasta lokacyjnego w Pucku w świetle badań archeologicznych. Warszawa.

Starski, M. 2016a. Stan badań archeologicznych nad małymi miastami Pomorza Gdańskiego w późnym średniowieczu. Archaeologia Historica Polona 23: I8I-213.

Starski, M. 20I6b. Późnośredniowieczne wyroby garncarskie z Pucka. Studium matomiasteczkowej wytwórczości garncarskiej na Pomorzu Gdańskim. Warszawa.

Starski, M. 20I7. Późnośredniowieczne naczynia ceramiczne z badań archeologicznych wschodniego bloku zabudowy przyrynkowej miasta lokacyjnego w Lęborku. Światowit Io(5I) fasc. B: 237-272.

Starski, M. 20I8. Skarszewy - Rynek, gm. Skarszewy, woj. pomorskie. Badania w 20I5 roku. Światowit I3-I4(54-55) fasc. A/B: 249-258.

Starski, M. 2019. Veränderungen in der Keramikproduktion im Danziger Pommern (Pomerellen) im Lichte der Untersuchung einer Putziger Töpferei aus dem i6. Jahrhundert. In H. Stadler (ed.), Keramik zwischen Werbung, Propaganda und praktischen Gebrauch, IO3-II9. Innsbruck, Nearchos 23.

Starski, M. 202I. From Heating Needs to Adaptation of Renaissance Patterns. Tiles from Small Towns of Pomerelia from the Second Half of the I4th Century to the End of the I6th Century. In G. Blažková and K. Matějková (eds), Post-medieval pottery in the spare time. Europa Postmedievalis 2020, 265-28I. Oxford.

Stephan, H.-G. 198I. Werrakeramik und Weserware. Zentren der Renaissancekeramik im Werraland und an der Oberweser. In H.-G. Stephan (ed.), Keramika an Weser, Werra und Fulda, 69-90. Fulda.

Stephan, H.-G. 1992. Keramik der Renaissance im Oberweserraum und an der unteren Werra. Köln. Beiträge der Archäologie zur Erforschung der Sachkultur der frühen Neuzeit. Zeitschrift für Archäologie des Mittelalters 7.

Tandecki, J. 1986. XVI-wieczne statuty toruńskiego cechu garncarzy i zdunów. Rocznik Toruński 17: 267-280.

Trzciński, Ł. 20II. Badania archeologiczne prowadzone w Chojnicach przy ulicy 3I Stycznia 8. Baszta II: 99-I22.

Trzeciecka, A. and Trzeciecki, M. 2002. Późnośredniowieczne naczynia gliniane. Z badań na terenie Centrum Dominikańskiego w Gdańsku - działki Szklary I - Szklary 5. In A. Gołembnik (ed.), Dominikańskie Centrum św. Jacka w Gdańsku. Badania archeologiczne. Vol. 2, 135-205. Warszawa, Światowit. Supplement Series P 9.

Verhaeghe, F. 1997. The archaeology of transition: a continental view. In D. Gaimster and P. Stamper (eds), The Age of transition. The archaeology of English culture I400-160o. Proceedings of a conference hosted by the society for Medieval Archaeology and the society for Post-Medieval Archaeology at the British Museum London I4-ISth November 1996, 25-43. Oxford.

Walenta, K. 2002. Badania wykopaliskowe przy ulicy Szewskiej-Podmurnej w Chojnicach. In K. Walenta (ed.), Chojnice i Pomorze Wschodnie w średniowieczu, 35-64. Chojnice.

Walenta, K., Trzcińska, K. and Trzciński, M. 200o. Nowe Miasto w Chojnicach w świetle badań wykopaliskowych. In L. Kajzer (ed.), Archeologia et Historia, Ksiegga Jubileuszowa dedykowana Pani Profesor Romanie Barnycz-Gupieńcowej, 403-420. Łódź.

Źródła dziejowe I9II. Źródta dziejowe 22. Polska XVI wieku pod względem geograficzno-statystycznym. Prusy Królewskie. J. T. Baranowski (ed.), Warszawa. 